
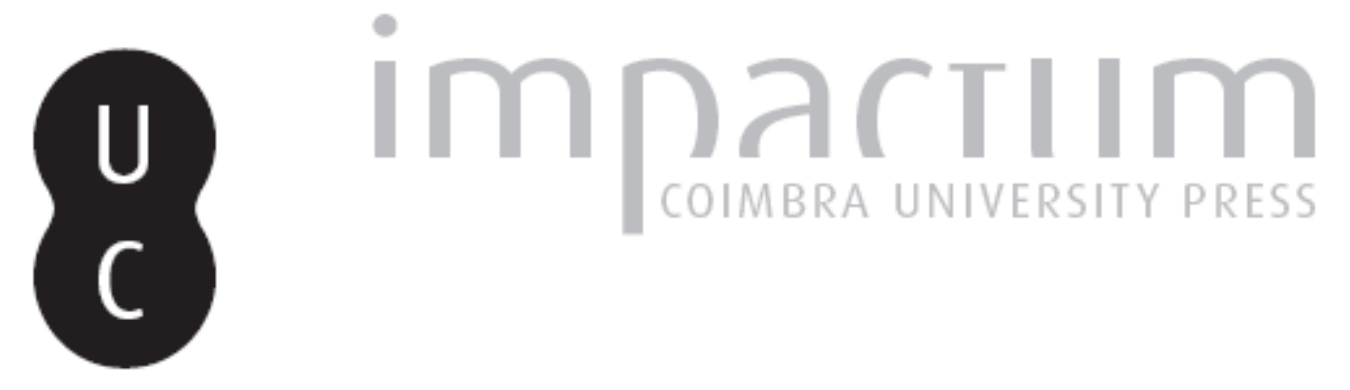

The fight against cancer in Poland before 1939

Autor(es): Magowska, Anita

Publicado por: Imprensa da Universidade de Coimbra

URL persistente:

URI:http://hdl.handle.net/10316.2/36781

DOI:

DOI:http://dx.doi.org/10.14195/1647-8622_12_18

Accessed : $\quad$ 26-Apr-2023 11:19:06

A navegação consulta e descarregamento dos títulos inseridos nas Bibliotecas Digitais UC Digitalis, UC Pombalina e UC Impactum, pressupõem a aceitação plena e sem reservas dos Termos e Condições de Uso destas Bibliotecas Digitais, disponíveis em https://digitalis.uc.pt/pt-pt/termos.

Conforme exposto nos referidos Termos e Condições de Uso, o descarregamento de títulos de acesso restrito requer uma licença válida de autorização devendo o utilizador aceder ao(s) documento(s) a partir de um endereço de IP da instituição detentora da supramencionada licença.

Ao utilizador é apenas permitido o descarregamento para uso pessoal, pelo que o emprego do(s) título(s) descarregado(s) para outro fim, designadamente comercial, carece de autorização do respetivo autor ou editor da obra.

Na medida em que todas as obras da UC Digitalis se encontram protegidas pelo Código do Direito de Autor e Direitos Conexos e demais legislação aplicável, toda a cópia, parcial ou total, deste documento, nos casos em que é legalmente admitida, deverá conter ou fazer-se acompanhar por este aviso. 
histórias da saúde

ESTUD OSD O SÉCULO

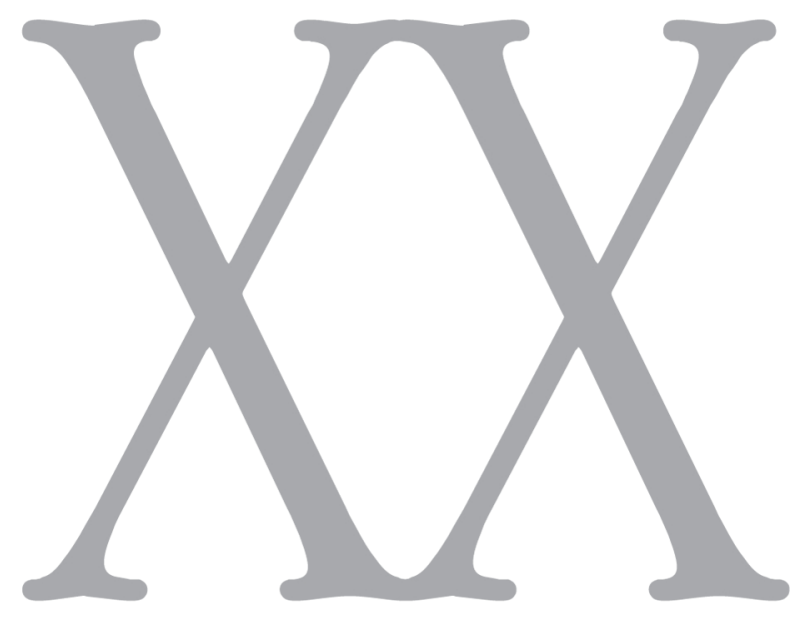

número 12 • 2012

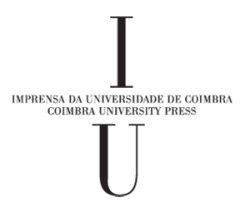




\title{
The fight against cancer in Poland before $1939^{1}$
}

\author{
Anita Magowska
}

${ }^{1}$ Some issues of this article refer to a work published in Polish: MAGOWSKA, Anita - "Iluzoryczność technologii medycznych a walka z rakiem w Polsce w latach 1921-1952" [The illusiveness of medical technologies and the fight against cancer in Poland in the years 1921-1952]. In MAGOWSKA, Anita Medycyna a technologia [Medicine and Technology]. Poznań: Wydawnictwo Naukowe UMP, 2012 (in the press). 
Anita Magowska, Doutora. Chair de History of Medical Sciences, Faculty of Medicine, Poznań University of Medical Sciences, Polónia. E-mail: anitamagowska@yahoo.com 


\section{Introduction}

The history of the fight against cancer has been the topic of numerous studies. They present the development of the concept of malignant and benign tumors, the health care system for cancer patients, social campaigns for early tumor detection, etc. Among all these works the one by Patrice Pinell deserves special attention, as it explains how in the $20^{\text {th }}$ century the "old incurable disease" was turned into a new object. ${ }^{1}$ From this perspective, an effective fight against cancer was conditioned by the development of scientific knowledge of tumors and its transfer to the society. So far, Polish literature has presented the fight against cancer from the perspective of its institutionalization, while the opening of new institutions for tumor diagnosing and treatment has been seen as improving the possibilities of cancer treatment. ${ }^{2}$ The present article focuses on the social and economic aspects of the fight against cancer and aims at determining whether all the members of the Polish society had access to modern tumor diagnostics and treatment in the interwar period or whether medical progress contributed to greater social discrepancies. The article is based on the archival sources from the Central Archives of Modern Records in Warsaw.

\section{The origins of the organized fight against cancer}

For centuries cancer was seen as an incurable disease foreshadowing imminent death, which caused deadly fear in patients and was of interest for doctors only if the tumor could be surgically removed. In the 19th century, as the medicalization of hospitals progressed, hospital statistics forced doctors to take interest in malignant tumors. The statistics showed that cancer was second only to tuberculosis as the primary cause of death of hospitalized patients. On the one hand, the high mortality rate of cancer patients tainted hospitals' reputation, on the other, patients with terminal cancer occupied beds which could otherwise be used by those who could be helped.

Such was the background against which special committees for the fight against cancer were founded (the first one was established in 1891 in England), which published periodicals and brochures, collected epidemiological data and raised funds for outpatient clinics, hospitals and shelters for cancer patients. As a result of their activity, many hospitals in Europe and both Americas opened separate cancer departments. They were separated from surgical departments, where cancer patients accounted for $6-8 \%$ of all patients, compared to $0.2-3 \%$ in other departments. ${ }^{3}$ Subsequently, cancer

1 PINELL, Patrice - "Cancer". In COOTER, Roger; PICKSTONE, John - Companion to Medicine in the Twentieth Century. $1^{\text {st }}$ ed London; New York: Routledge. 2003. ISBN 0415286034. p. 671-686

2 SUPADY, Jerzy - "Organizacje i instytucje do walki z rakiem w Polsce w latach 1906-1939" [Organizations and institutions for the fight against cancer in Poland in 1906-1939]. 1st Ed. Łódź: Adi, 2003. 13 p. ISBN 8385815848.

3 WEJNERT, Bronisław - "Stosunek szpitalnictwa do chorych na raka wobec rozpowszechnienia się tej choroby [The attitude of the hospital system towards cancer patients in the face of spread of the disease]". Polska Gazeta Lekarska [The Polish Medical Newspaper]. ISSN 0860-0392. N. 22 (1922) p. 459-460. 
departments were equipped with radiology and diagnostic laboratories, which, over time, developed into research institutes examining the causes, structure, development, experimental transplantation, and treatment of tumors. In the early 20th century such countries as England, the Austro-Hungarian Empire, Japan, France, Spain, the Netherlands, Germany, Russia and the USA had cancer research institutes. It is noteworthy that cancer research was conducted in countries with strong economies, most of which were engaged in colonial expansion. In 1906 the International Union of People against Cancer was established in Berlin in order to coordinate the activities of cancer research centers. ${ }^{4}$

The fight against cancer in particular countries was modeled on the earlier struggle against tuberculosis but also followed the traditions of these countries. In the USA it all started with a citizens' initiative of a group of surgeons and insurance companies' representatives, who in 1913 founded the American Society for the Control of Cancer (ASCC). ${ }^{5}$ Thanks to the financial participation of insurance companies, ASCC could afford to buy out the world's supply of radium. ${ }^{6}$ The organization became famous in 1919, when the three axioms of the effective fight against cancer were announced: in early stages cancerous lesions are local; early diagnosis and treatment can save a patient's life; and ignorance and late cancer treatment are the cause of death of thousands of people. ${ }^{7}$ Initially, the activities of ASCC were limited to setting up specialist outpatient clinics, which referred patients diagnosed with cancer to hospitals. Hospitals, however, lacked both the properly trained doctors and the necessary equipment, as a result of which the patients could not be saved, which strengthened the belief that cancer was indeed an incurable disease. Over time ASCC started to open its outpatient clinics only at the hospitals which were properly prepared, thus creating an organizational framework for the fight against cancer. ${ }^{8}$

In Sweden the fight against cancer was initiated by the government, who granted high subsidies for its organization, providing free treatment to the poorest citizens. In the years 1915-1922 only three hospitals specializing in tumor treatment were established in Sweden, however, they were equipped with nearly 9 grams of radium. ${ }^{9}$ In France - the cradle of radiotherapy - the fight against cancer was much delayed as a result of the perennial unwillingness of the French doctors to cooperate with surgeons. It was not until the end of the First World War that hospitals for cancer patients, which employed interdisciplinary teams of doctors, including hematologists, histopathologists, surgeons and radiologists, were established. In the early 1930s there

4 PINELL, Patrice - "Cancer”..., p. 674.

5 LERNER, Barron H. - "The breast cancer wars: hope, fear, and the pursuit of a cure in twentiethcentury America. $1^{\text {st }}$ ed. Oxford: Oxford University Press, 2001. ISBN 9780195142617. p. 30-31.

6 SKOWRONEK, Janusz - "Brachytherapy in Greater Poland Cancer Centre and in Poznan - the past and the present”. Journal of Contemporary Brachytherapy. ISSN 1689-832X. N. ${ }^{\circ}$ (2009) p. 50-56.

7 LERNER, Barron H. - "The breast cancer...", p. 30.

8 Central Archives of Modern Records in Warsaw (CAMR), Collection of the Ministry of Social Welfare (CMSW), 1407, p. 4-5.

9 Ibidem, p. 9-10. 
were 6 large and 13 smaller, provincial cancer treatment centers in France, which were equipped with the total of over 20 grams of radium and several dozen deep therapy x-ray machines. Similarly to Sweden, underprivileged cancer patients were treated free of charge. ${ }^{10}$

At the time Poland was under Austrian, Prussian and Russian rule, which hampered the development of the Polish higher education system, which, paradoxically, was conductive to the transfer of Western European medical knowledge to Polish society. Polish doctors graduated from German, Swiss, French, Austrian and Russian universities and were familiar with the international trends in fighting cancer. In 1898 the Society for the Care of Terminally Ill was founded in Warsaw and opened a shelter for 70 terminally ill and poor women, most of whom suffered from cancer. The shelter was too small to meet social needs.

In the early twentieth century Polish doctors collected statistical data concerning the incidence of cancer on Polish lands. Dr. Józef Jaworski demonstrated that in 1882-1904 in Russian Poland cancer caused 6.26 - 7.40 deaths per 10000 citizens, the figure being comparable to the mortality rates in Austria, Germany and the USA, and lower than in Denmark and Switzerland. The German and American statistics demonstrated that the mortality rate due to cancer increased by nearly $20 \%$ every ten years, while nearly $20 \%$ of all neoplasm remained undiagnosed, which was corroborated by the data collected by Jaworski. Yet another doctor, Bronisław Wejnert, demonstrated that $25 \%$ of the cancer patients hospitalized in Warsaw died, because they were admitted in the terminal stage of the disease. ${ }^{11}$ In 1906, on the initiative of Dr. Jaworski, The Committee for the Treatment and Research of the Disease Known as Cancer was established to create a specialized hospital, however, it did not expand its activities due to the lack of funds. ${ }^{12}$

Health care for cancer patients in Poland before 1939

In the late 1918 Poland regained independence, however, the country was economically devastated by the three superpowers and the fronts of the First World War, which had swept across the country several times. At the time the first Polish outpatient clinic for cancer patients had been operating in Łódź for several months. It was established on the initiative of Dr. Stanisław Sterling-Okuniewski (formerly the organizer of the fight against tuberculosis) at St. Alexander Hospital in Eódź to provide care for several hundred people a year, most of whom were women. At first the outpatient clinic did no more than diagnose tumors and radium therapy was not available in Łódź until 1926, when a special ward for women suffering from cancer

10 PINELL, Patrice - “Cancer”..., p. 677-678.

11 WEJNERT, Bronisław - "Stosunek szpitalnictwa...", p. 460-461.

12 WRONKOWSKI, Zbigniew - "Rozwój walki z rakiem w Warszawie [The development of the fight against cancer in Warsaw]". In RAMLAU, Cezary - Materiaty do historii walki z rakiem w Polsce [The materials concerning the history of the fight against cancer in Poland]. $1^{\text {st }}$ ed. Poznań: Wydawnictwo Uczelniane AM, 1998. ISBN 8385439048. p. 140-157. 
was set up at St. Joseph Hospital. The ward was closed five years later, ${ }^{13}$, when the Institute for Radium Treatment, equipped with a deep therapy x-ray machine and $30 \mathrm{mg}$ of radium, had been opened in this city. The radium supply was constantly increased and reached $250 \mathrm{mg}$ in $1939 .{ }^{14}$ The Institute depended on the patients' fees and any possible financial shortfalls were supplemented with the funds of the Łódź Society for the Fight Against Cancer. ${ }^{15}$ Moreover, in the mid 1930s the department for cancer patients at the Bethlehem Hospital, the complex of diagnostic laboratories and the shelter for the terminally ill were also opened in Łódź. Health care for cancer patients in Łódź in the interwar period was well organized, however, it should be mentioned that the initial radium reserves were insufficient to treat all the tumors. ${ }^{16}$

Warsaw was the second Polish city where care to cancer patients was provided. In 1921 an organization which existed before the First World War was reactivated and renamed the Polish Committee for the Fight Against Cancer. In 1924 the Committee opened an outpatient clinic for cancer patients at St. Lazarus Hospital in Warsaw, where tumors were only diagnosed. ${ }^{17}$ Patients diagnosed with cancer were referred for paid radium treatment to the department headed by Dr. Stanisław Gądek, where they had to pay 250 zloty for the radium treatment and cover the costs of hospital stay, or to the Elizabethan Sisters' Hospital, where the price of radium therapy was 150 zloty (for comparison, the average salary of a clerk was 100 zloty). The patient decided whether he or she wanted to undergo the treatment, depending on his or her financial standing. Most of the patients were women diagnosed with uterus cancer who depended financially on their husbands and had no savings of their own. If their husbands were unemployed or underpaid, they were forced to give up treatment, which undermined the sense of early cancer diagnosis ${ }^{18}$.

Aside from the said Committee, the Society of the Radium Institute, founded in 1921 on the initiative of Maria Skłodowska-Curie, pursued the fight against cancer. It was supposed to establish a central research and treatment institution specializing in cancer research and treatment, after the fashion of Institut du Radium in Paris. ${ }^{19}$.

13 FIJAŁEK, Jan, INDULSKI, Janusz - "Opieka zdrowotna w Łodzi do roku 1945. Studium organizacyjno-historyczne" [Health care in Łódź until 1945. Organizational and historical study]. $1^{\text {st }}$ ed. Łódź: Instytut Medycyny Pracy im. Jerzego Nofera 1990. PB 3982/91. p. 323; SUPADY, Jerzy - Organizacje i instytucje..., p. 11-12.

${ }^{14}$ NAGAŃSKI, Tadeusz - "Historia i rozwój lecznictwa onkologicznego w Łodzi i regionie" [The history and development of oncologic treatment in Łódź and in the region]. In RAMLAU, Cezary - Materiaty do historii walki z rakiem $w$ Polsce [The materials concerning the history of the fight against cancer in Poland]. $1^{\text {st }}$ ed. Poznań: Wydawnictwo Uczelniane AM, 1998. ISBN 8385439048. 95-96 p.

15 SUPADY, Jerzy - “Organizacje i instytucje...”, p. 47-50.

16 NAGAŃSKI, Tadeusz - “Historia i rozwój...”, p. 94-96.

17 SUPADY, Jerzy - "Organizacje i instytucje...”, p. 44.

18 CAMR, CMSW, 643, p. 5-6.

19 TOWPIK, Edward - “Twarze Instytutu. Dawni pracownicy Instytutu Radowego, Instytutu Onkologii i Centrum Onkologii im. Marii Skłodowskiej-Curie w Warszawie 1932-2009” [The Faces of the Institute. The former employees of the Radium Institute, and Maria Skłodowska-Curie Oncology Institute and Oncology Center in Warsaw 1932-2009]. Nowotwory [Tumors]. ISSN 0029-540X. Suppl.(2009) p. 7. 
It was difficult to accomplish this task in a country as economically weak as Poland. The subsidies granted by the government were low, while the amounts raised from the public were insufficient. The construction took years to complete and when it was finally over, there was no money left to equip the hospital rooms. In order to admit the first patients in 1932 the Institute had to take out a mortgage loan, which burdened its finances until the outbreak of the Second World War. ${ }^{20}$

At first doctors approached the Radium Institute with reserve and refused to refer patients to this institution. For this reason in the first year of its activity, only half of the 45 beds were occupied, but after a few years the number of beds had to be doubled. The number of doctors grew even faster. In 1932 there were two doctors, compared to 10 doctors after five years. Pursuant to the regulations in force at the time, the wards at the Radium Institute were divided into three classes, the poorest conditions being offered in 20-bed third-class wards, which were intended for the underprivileged patients. ${ }^{21}$ The laws in force provided for the free health care for the poor, however, at the Radium Institute the poor were charged 100 zloty for radium treatment and were offered discounts or free treatment when they were diagnosed with advanced malignant neoplasm. Few people were insured at the time, therefore, insurance policies relatively rarely covered cancer treatment, which was also infrequently refunded by the local governments. Since the Radium Institute charged the poor for treatment, the national authorities refused to approve of its articles of association. Appealing against this decision, the director of the Institute pointed out that charging fees was a necessity, since the subsidies granted by the government totaled 25000 zloty per year, while $100 \mathrm{mg}$ of radium cost 15000 zloty, a radiologist earned 250 zloty a month and was provided with free accommodation, while a nurse earned 100 zloty a month and benefited from free accommodation and board. Moreover, high-power $\mathrm{x}$-ray lamps had to be frequently replaced and the aforesaid mortgage loan had to be repaid. Thus, even the poorest patients had to be charged for their treatment. In the case of uterus cancer the fees amounted to 600 zloty, however, as emphasized by Dr. Franciszek Łukaszczyk, the head of the Radium Institute, they were still lower than in private practices. ${ }^{22}$

This most important Polish cancer research and treatment institution was equipped with less radium and new generation $\mathrm{x}$-ray machines than the Western European centers. In June 1934 the Institute owed just only 1 gram of radium, bought with the contributions of the Polish community in the U.S.A. and donated by Maria Skłodowska-Curie in the early 1920s, which corresponded to provincial centers in France or Sweden. In 1938 the Institute owed a gram and a half of radium, still a lot less than other European institutions of this type. ${ }^{23}$ Moreover, it had five deep therapy

\footnotetext{
${ }^{20}$ CAMR, CMSW, 643, p. 11-16.

21 WRONKOWSKI, Zbigniew - “Rozwój walki...”, p. 140-157.

22 CAMR, CMSW, 643, p. 78-80.

23 Ibidem, p. 89.
} 
x-ray machines, which - according to Dr. Łukaszczyk - allowed the treatment of no more than 800 patients a year. ${ }^{24}$

Throughout the interwar period the government was not able to support the fight against cancer due to the poor condition of the public finances. In the 1930s, when the Committee for the Fight against Cancer in Vilnius and the Polish Anticancer Institute Association in Lvov applied for the purchase of radium with the Ministry of Social Welfare, their applications were referred to the private Foundation of Jakub Potocki along with a recommendation for support, as the national treasury was empty. ${ }^{25}$ In the face of such important and insolvable financial problems, university hospitals, Elizabethan Sisters' Hospitals and private medical practices became important cancer research and treatment centers. The most famous ones included Aleksander Oszacki's (1883-1945) research laboratory at the internal department of St. Lazarus Hospital in Cracow and the anticancer center of the Chair of Surgery of the Poznań University, founded in 1928 by Prof. Antoni T. Jurasz (1882-1961), equipped with deep therapy $\mathrm{x}$-ray machines and, since 1931, with $144 \mathrm{mg}$ of radium in 75 platinum brachytherapy needles ${ }^{26}$. One of A. T. Jurasz's assistants, Dr. Stanisław Bylina, was trained in Prof. Stanford Cade's Oncologic Institute at the Westminster Hospital School in London, thanks to the scholarship of the Ministry of Religions and Public Education ${ }^{27}$.

The achievements of the Chair of Radiology of the Poznan University in the field of fight against cancer are also worth mentioning. Prof. Karol Mayer, the Director of the Chair, purchased two deep therapy x-ray machines, which were used to treat patients transported from two Poznan hospitals. ${ }^{28}$ Mayer developed the basics of the $\mathrm{x}$-ray rotation therapy, using a rotating bed powered by an electric engine ${ }^{29}$. This Chair became an important center for training doctors in $\mathrm{x}$-ray diagnostic imaging and x-ray therapy. In the 1920s Poznań also had a radium treatment center for insured patients. ${ }^{30}$ In Vilnius, on the other hand, modern cancer diagnostics and treatment were not available until 1936, when the Research and Treatment Department for Fighting Cancer of Stefan Batory University received $33 \mathrm{mg}$ of radium, i.e. the amount required to treat skin tumors. ${ }^{31}$

${ }^{24}$ CAMR, CMSW, 1407 , p. 1-19.

25 Ibidem, p. 7.

26 SKOWRONEK, Janusz - "Brachytherapy in Greater Poland...”, p. 50-56.

${ }^{27}$ GRANATOWICZ, Józef - "Dzieje Kliniki Chirurgicznej UP” [The history of the Surgical Clinic of the Poznań University]. Acta Medicorum Polonorum. ISSN 2083-0343. N. 2 (2012) p. 37.

28 MEISSNER, Roman - "Radiologia poznańska w latach 1896-1946" [Poznań radiology in the years 1896-1946]. In LESZCZYŃSKI, Stanisław - Historia radiologii polskiej na tle radiologii światowej [The history of Polish radiology in comparison to world's radiology]. Kraków: Medycyna Praktyczna, 2000. p. 210. ISBN 8388092073.

${ }^{29}$ MAYER, Karol - "Leczenie nowotwor6w złośliwych" [The treatment of malignant tumors]. Polski Przeglad Chirurgiczny [The Polish Surgical Review]. ISSN 0032-373X. N. . 5-6 (1933) p. 586-591.

${ }^{30}$ MEISSNER, Roman - "Radiologia poznańska...”, p. 212.

31 SUPADY, Jerzy - “Organizacje i instytucje...”, p. 52. 
Social campaigns promoting early cancer diagnosis triggered an eruption of social cancerophobia, and lead many people to believe that their various ailments were the first symptoms of cancer. As a result of the rising demand for early tumor diagnosis and modern treatment, new cancer treatment technologies turned into a competitive factor used by private medical practices. Doctors purchased small amounts of radium and $x$-ray machines and subsequently opened cancer treatment centers addressed to wealthy patients. Over one hundred facilities of that type were created in Poland. ${ }^{32}$ The Radiology Laboratory of Dr. Tadeusz Alkiewicz (1891 - 1952), a former assistant of Prof. Hermann Rieder (1858-1932), the pioneer of the use of contrast in radiology, in Munich, which operated in Poznań since 1921, was one of such facilities. Apart from working at his own practice, he also headed the radiology laboratories at the military hospital and the Elizabethan Sisters' Hospital in Poznań. ${ }^{33}$

The shared medical practice of Kazimierz Węckowski, Jan Sitkiewicz and Aleksander Mańkowski in Brześć upon Bug, who in 1938 advertised their combined treatment (surgery, $\mathrm{x}$-ray and radium) for stomach, esophagus, breast, uterus and bladder cancer, and skin tuberculosis, is an example of a commercial undertaking addressed to well-off patients. Initially, the aforesaid Dr. Węckowski worked at the Radium Institute of the Union Hospital in Poznań, and after several years he moved to Lvov, where he founded the Polish Anticancer Institute Association. ${ }^{34}$ He resigned due to interpersonal conflicts and subsequently established a commercial private practice based on several dozen milligrams of radium. ${ }^{35}$

Thus, the possibilities of cancer treatment in the interwar Poland were limited. It was estimated that they only met one tenth of the total demand. Clinical hospitals, hospital departments and private institutions were only equipped with small amounts of radium, usually below $200 \mathrm{mg}$. Private hospitals were not able to offer combined treatment. As it was emphasized in 1937 by Dr. Franciszek Łukaszczyk, despite the existence of over 100 large and small tumor diagnostics and treatment institutions, few patients were cured of cancer. In the case of laryngeal cancer, it was no more than a dozen or so people in the whole country, including the former patients of the Radium Institute in Warsaw. ${ }^{36}$

\section{Increase in cancer detection}

The concept of the fight against cancer did not contribute to decreasing cancer incidence and mortality rate, on the contrary, it contributed to the increase in tumor detection. Doctors trained at university hospitals were able to correctly diagnose tumors, both in living and dead patients, which caused a statistical increase in the number of cancer-related deaths. Cancer death rate statistics in hospitals revealed that the bigger

\footnotetext{
32 CAMR, CMSW, 643, p. 5; 1407, p. 20.

33 SUPADY, Jerzy - “Organizacje i instytucje...”, p. 59.

34 SKOWRONEK, Janusz - "Brachytherapy in Greater Poland...”, p. 52.

35 CAMR, CMSW, 643, p. 118-120.

36 CAMR, CMSW, 1407, p. 1-19.
} 
the city, the higher mortality rate. For instance, in 1927 there were 88.0 cancer-related deaths for every 100000 citizens, compared to 111.6 deaths in Warsaw alone. It will be recalled that only paid cancer treatment was available in Warsaw at the time. ${ }^{37}$

In 1934, based on 6,421 cases of cancer, it was determined that most patients were between 45 and 54 years of age. The leading cancer for men was stomach cancer $(20.14 \%)$, while for women - cervical cancer $(18.54 \%)$. The incidence of the remaining types of cancer was below $10 \%$. Moreover, the incidence of cancer was compared in Jews and Christians. It turned out that Jews were affected with cancer at a later age than Christians. The incidence of stomach cancer in Jews and Christians was comparable, while the bowel and rectal cancer was relatively frequent in Jews and hardly ever occurred in Christians. The incidence of cervical cancer, on the other hand, was four times higher in Christian women than in Jewish women, who, in turn, were more prone to breast cancer. ${ }^{38}$

The statistics of the Radium Institute in Warsaw provided even more detailed information about the incidence of malignant tumors and the availability of treatment. In 1935, 226 persons were qualified for treatment, however, only 167 persons (including 127 women) took advantage of it (the others most likely could not afford it). Nearly one third of the hospitalized patients were aged between 51 and 61, the second largest group were patients aged 41-50 and 61-70 (31 persons). 133 patients were Christian and 34 were Jewish. Most of the patients of the Radium Institute were supported by their families (61 persons), yet another large groups were workers (39 patients) and the unemployed ( 25 patients). The detected malignant tumors included: 75 cases of cervical cancer, 22 cases of skin cancer, 15 cases of breast cancer, 12 cases of lip cancer and 7 cases of eyelid cancer. 112 patients were treated with radium, 25 patients with $\mathrm{x}$-ray, and 30 patients with both. Out of all the patients treated with radium only one was treated free of charge, 68 patients covered the cost of their treatment, while the costs of treatment of the remaining patients were covered by insurance companies or local governments. The foregoing data allow the conclusion that unemployed women aged 40-70 diagnosed with cervical or breast cancer, often in a terminal stage, constituted a large group of the Institute patients. ${ }^{39}$

Similar data came from the Polish Anticancer Institute Association in Lvov. In 1936, 231 patients were treated in the department of St. Lazarus Hospital in Lvov, i.e. more than at the Radium Institute in Warsaw. $75-80 \%$ of the patients could not afford to cover the costs of treatment. 95 patients were treated in outpatient clinics. Both were treated with the total of 3,219 sessions of deep x-ray therapy, and there was no radium available. Until 1936 the Association received a small subsidy of 150 zloty a month from the Ministry of Social Welfare. ${ }^{40}$

By analogy to foreign epidemiological data, the experts from the Radium Institute in Warsaw estimated that in Poland with the population of nearly 33 million, 70000

\footnotetext{
37 WRONKOWSKI, Zbigniew - “Rozwój walki...”, p. 140-157.

38 CAMR, CMSW, 1407, p. 25-27.

39 CAMR, CMSW, 643, p. 8-10.

${ }^{40}$ CAMR, CMSW, 644, p. 1.
} 
people suffered from cancer, 35000 were dying of it, an only $2000-3000$ patients benefited from specialized treatment. The calculations of Prof. Fornell from Stockholm were often quoted, who claimed that $10 \%$ of cancer patients could be treated surgically, $20 \%$ could be cured or temporarily cured of the disease with radium and x-ray, while the condition of $30 \%$ of patients could be significantly improved thanks to combined treatment. ${ }^{41}$ It was believed that the remaining $40 \%$ of patients could not be cured and therefore they were refused hospital care and referred to shelters, ${ }^{42}$ commonly referred to as death houses and feared by patients. For instance, in 1933 several hundred people were refused treatment at the Radium Institute in Warsaw, only 3 of whom agreed to be admitted to a shelter for the terminally ill. ${ }^{43}$

\section{Economic aspects of cancer treatment}

The services of private cancer treatment centers were addresses primarily to wealthy patients who could afford the treatment. The treatment of the poor and the provision of health care for terminally ill cancer patients remained a problem throughout the interwar period, as there were no sources of funding available. In march 1934, the representatives of the Society of the Radium Institute, Prof. Ludwik Paszkiewicz and Dr. Franciszek Łukaszczyk pointed out that the work of anticancer outpatient clinics which were not based on properly equipped hospitals: "cannot have positive practical effects in the fight against cancer, since both the diagnosis and the assessment of the treatment methods suitable in a given case are often very difficult in the case of malignant tumors and should be made by doctors who are directly involved in the treatment". ${ }^{44}$ In their opinion, the factors which hampered cancer treatment included not only belated medical consultation but also delayed histopathological tests and rather inappropriate ways of sending the material for analysis, which could lead to misdiagnosis. Since the early days of its operation, the Institute raised doctors' awareness of the proper methods for collecting tests samples and clinical data required by the histopathologist. The price of diagnostic tests was reduced to a minimum and many tests were performed free of charge. ${ }^{45}$

In 1934, in the face of shortage of funds for the fight against cancer, the Society of Radium Institute by name of Maria Skłodowska-Curie presented a project of its centralization to the Ministry of Social Welfare. The suggested solutions were rather utopian and included the opening of several well-equipped central institutes, the training of medical students and doctors in malignant neoplasm diagnostics and

\footnotetext{
41 CAMR, CMSW, 1407 , p. 1-17.

42 WEJNERT, Bronisław - "Walka z rakiem w Polsce obecnie i w najbliższej przyszłości" [The fight against cancer in Poland at present and in the near future]. Nowotwory [Tumors]. ISSN 0029-540X. N. ${ }^{\circ}$ 5 (1932) p. 327-333.

43 CAMR, CMSW, 1407 , p. 1-17.

${ }^{44}$ CAMR, CMSW, 643, p. 1-2.

45 Ibidem, p. 2.
} 
treatment, and providing health care for terminal cancer patients. ${ }^{46}$ Since 1934 the newly established Division for the Fight against Cancer of the National Supreme Health Council was involved in the organization of cancer treatment centers in university cities $^{47}$. Moreover, in the early 1938 the Polish Anticancer Association was founded, which united all the existing organizations, and operated throughout the country. ${ }^{48}$ It is worth emphasizing that high-power x-ray lamps were purchased in England or Sweden, while radium was mostly bought in the USA. ${ }^{49}$

\section{Summary}

The fight against cancer in the interwar period contributed to the creation of a new, be it invisible, borderline in Europe between the countries which pursued imperial policy, such as Germany, and the conquered countries, such as Poland. Only the militarily and economically expansive countries could afford to finance cancer research and treatment, as a result of which they monopolized the production of radium (which was obtained in African colonies) and new-generation x-ray machines, and subsequently, the international trade in medical technologies and drugs used in oncology. Thus, the political situation of the European countries at the turn of the twentieth century shaped the international health market for many years.

In economically weak countries, such as Poland, cancer patients' chances of survival were incomparably lower than in affluent countries. At the Radium Institute in Warsaw the problem of the shortage of funds was solved through the preliminary selection of patients (patients diagnosed with advanced cancer were refused hospitalization) and charging the majority of patients for treatment. In the light of archival documents, the Polish Committee for the Fight against Cancer had its own radium reserves and still referred patients for treatment to private institutions, as a result of which some patients gave up treatment, which at the time often had the nature of an experiment. It should be emphasized that in all the countries which undertook the fight against cancer, it contributed to social integration. Moreover, the raising of funds for the purchase of radium in the interwar Poland contributed to the enhancement of the relations with Polish community in the U.S.A. and to the development of scientific cooperation with the USA.

${ }^{46}$ WRONKOWSKI, Zbigniew - "Twórcy wspótczesnej onkologii" [The creators of modern oncology]. In RAMLAU, Cezary - Materiaty do historii walki z rakiem $w$ Polsce [The materials concerning the history of the fight against cancer in Poland]. $1^{\text {st }}$ ed. Poznań: Wydawnictwo Uczelniane AM, 1998. ISBN 8385439048. p. 23. - After the Second World War Poland received several grams of radium thanks to UNRRA.

47 CAMR, CMSW, 1407, p. 18.

48 Ibidem, p. 20.

${ }^{49}$ CAMR, CMSW, 643, p. 145-148. 